\title{
Vitamin, mineral and iron supplementation in pregnancy: cross-sectional study
}

\author{
M. Leppee', J. Culig ${ }^{1,2}$, M. Eric ${ }^{3}$, J. Boskovic ${ }^{4}$, N. Colak ${ }^{5}$
}

\footnotetext{
${ }^{1}$ Andrija Stampar Institute of Public Health 16, Mirogojska, Zagreb, Croatia, 10000

${ }^{2}$ School of Medicine, Josip Juraj Strossmayer University

4, Josipa Huttlera, Osijek, Croatia, 31000

${ }^{3}$ School of Medicine, University of Novi Sad 3, Hajduk Veljkova, Novi Sad, Serbia, 21000

${ }^{4}$ Faculty of Pharmacy and Biochemistry

1 A. Kovacica, Zagreb, Croatia, 10000

${ }^{5}$ Colpharm d. o. o.

16, Trnska cesta, Siroki Brijeg, Bosnia and Herzegovina, 88220

marcel.leppee@stampar.hr
}

\begin{abstract}
Aim. To assess the use of vitamin, mineral and iron supplements during pregnancy in Zagreb and Novi Sad. Methods. The study was conducted by use of a structured standardized questionnaire consisting of two parts, $i$. e. data obtained by maternal interview and hospital records. It is designed as a cross-sectional study in two countries (Croatia and Serbia). The study included 893 pregnant women from Zagreb and 6099 pregnant women from Novi Sad. Results. In Zagreb, pregnant women reported highest utilization of vitamin-mineral supplements $(n=508 ; 56.9 \%)$, whereas in Novi Sad these supplements ranked third ( $n=408 ; 20.3 \%)$, following tocolytics and iron supplements. There was no statistically significant difference in the prevalence of congenital malformations between neonates at in utero exposure to vitamins, minerals and iron supplements and those without such exposure in either Zagreb or Novi Sad arm, with the exception of iron and calcium supplementation in the Zagreb arm. Conclusions. In spite of certain study limitations, the results obtained pointed to the unreasonable and potentially harmful use of these supplements in pregnant women from Zagreb.
\end{abstract}

Keywords: vitamins, minerals, pregnancy, Zagreb, Novi Sad.

Introduction. Vitamins are substances necessary for life. Quite frequently, use of supplements containing multiple vitamins (multivitamins) is routinely advised to pregnant women. Multivitamins usually contain vitamins A (retinol), D (calciferol), C (ascorbic acid), E (tocopherol), vitamin $\mathrm{B}$ complex, $\mathrm{B}_{1}$ (thiamine), $\mathrm{B}_{2}$ (riboflavin), $\mathrm{B}_{3}$ (niacin), $\mathrm{B}_{5}$ (pantothenic acid), $\mathrm{B}_{6}$ (py-

(C) Institute of Molecular Biology and Genetics NAS of Ukraine, 2010 ridoxine), vitamin $\mathrm{B}_{12}$ and folic acid. These supplements may also contain iron, calcium, and other minerals. Vitamin utilization in pregnancy varies from country to country. Although necessary for life, vita$\min \mathrm{K}$ (menadione) is not included in vitamin supplements because it is found in food in adequate amounts. Liposoluble vitamins A, D and E may exert teratogenic effects when administered in high doses. Water soluble vitamin $\mathrm{C}$ and $\mathrm{B}$ complex vitamins are 
safe in doses recommended by the National Academy of Sciences (NAS). Vitamin deficiency can also cause serious problems.

Vitamins are classified into Food and Drug Administration (FDA) categories according to dosage.

The role of vitamins in the prevention of some congenital malformations remains a matter of dispute. Two different types of congenital anomalies, i. e. cleft lip and neural tube defects, were in the focus of research into the use of vitamins in pregnancy. Extremity shortening has been defined as a third type of anomaly potentially associated with the use of vitamins in pregnancy.

Numerous studies performed to date have failed to offer an unambiguous statement on the need of vitamin-mineral supplementation therapy in pregnancy. Most authors believe that appropriate diet rich in vitamins and minerals is necessary for the fetus to undergo regular growth and development. In case of normal maternal diet and adequate intake of all nutrients, there is no need for supplementation $[1,2]$.

However, modern lifestyle and unfavorable dietary habits frequently result in inappropriate diet during pregnancy, thus imposing the need of target education of pregnant women and women planning pregnancy, along with the intake of food supplements in pregnancy [3].

One of the most important studies was the international multicenter study entitled Collaborative Study on Drug Use in Pregnancy (DUP), initiated in 1987 by the Mario Negri Institute (Milan, Italy) and cosponsored by the World Health Organization (WHO) Regional Office for Europe (Copenhagen, Denmark). Two centers from former Yugoslavia, i. e. Zagreb and Novi Sad were involved.

The study included 14778 pregnant women from 148 maternity wards in 22 countries on 4 continents. There were 609 women from Zagreb and 296 women from Novi Sad. Study results showed great country to country differences determined by the broad spectrum of medical care, public health issues and customs found in the various countries included in the study. Only $14 \%$ of women received no medication, whereas $86 \%$ of women were taking a mean of 2.9 drugs during pregnancy [4-7]. Iron and vitamin supplements accounted for $50 \%$ of drugs administered in pregnancy.
However, it is beyond doubt that the use of some drugs in pregnancy exceeds the research based medical recommendations. This primarily applies to the routine use of iron supplements in pregnancy in industrialized countries, where the prevalence of anemia does not exceed $15 \%$.

Teratogenic factors show selectivity according to gestational periods. It is well established that firsttrimester ( $3^{\text {rd }}$ to $8^{\text {th }}$ week of gestation) drug exposure is critical for the fetus. The period of cell proliferation is the initial stage of development, from conception to early postimplantation (the initial two weeks of gestation in humans). During this period, teratogens exert the «all or nothing» effect, i. e. the embryonal effect is either very profound and tissue lesions severe, leading to embryonal death, or only few cells are involved, so that the embryo can easily replace them and develop normally. The next stage, organogenesis $\left(3^{\text {rd }}\right.$ to $8^{\text {th }}$ week of gestation in humans), is a period of highest teratogen sensitivity because of the fast cell differentiation when the lesions cannot be corrected. Embryonic phase extends from the period of cell proliferation to the completion of organogenesis. Fetal phase as the third stage of development is relatively insensitive to teratogens, however, functional impairments, growth retardation and even fetal death may occur in this period. This stage is characterized by growth and functional maturation of the already formed organs and systems.

The aim of the study was to assess the prevalence of vitamin and mineral use and the rate of congenital malformations in neonates at in utero exposure to these substances.

Materials and Methods. One arm of the study (one-month study) was performed at four maternity hospitals in Zagreb, Croatia: University Department of Gynecology and Obstetrics, Zagreb University Hospital Center; University Department of Gynecology and Obstetrics, Sestre milosrdnice University Hospital; University Department of Gynecology and Obstetrics, Merkur University Hospital; and University Department of Gynecology and Obstetrics, Sveti Duh General Hospital (part 1).

The other arm of the study (one-year study) was performed at the Genetic Counseling Unit, Institute for Children and Adolescents, University Department of Gynecology and Obstetrics, and Department of Patho- 
logy and Histology, Clinical Center in Novi Sad, Serbia, and included pregnant women presenting to the Genetic Counseling Unit for risk pregnancy and pregnant women hospitalized at University Department of Gynecology and Obstetrics for delivery or abortion (part 2).

The study included 893 pregnant women from Zagreb and 6099 pregnant women from Novi Sad. Informed consent on their participation in the study was obtained from all study subjects. The study was approved by independent Ethics Committee of the School of Medicine.

Data were collected from the following sources:

1) questionnaire for pregnant women, filled in by a physician, containing two types of data: hospital records and information obtained by interview;

2) thorough physical examination of the neonate, performed by a neonatologist according to standard protocol;

3) thorough pathologic examination of the fetus, performed by a pathologist according to standard protocols.

Vital data on the newborns, maternal data on previous deliveries and on medication taken between hospital admission and delivery were collected from hospital records.

The other part of the questionnaire contained data obtained by interview on the mother's age, level of education, use of contraception, ultrasound (US) studies during pregnancy, X-rays during pregnancy, and use of drugs, alcohol, nicotine and opioid substances during pregnancy. Following delivery or abortion, the newborns and fetuses were thoroughly examined and monitored for the occurrence of minor or major malformations. The use of vitamins, minerals and iron supplements, and the existence of congenital malformations in newborns and fetuses at in vitro exposure to these drugs were monitored according to gestational trimesters.

The study was conducted according to the Clinical Epidemiological Trial Protocol and in line with the By-Law on Clinical Trials and Good Clinical Practice, implying due respect of all provisions of Helsinki.

Declaration and recommendations of the World Medical Association of Physicians Performing Biomedical Trials in Humans.
Table 1

Drugs most commonly used in pregnancy

\begin{tabular}{c|c|c}
\hline \multirow{2}{*}{ Drug } & $n$ & Pregnant women \\
\cline { 2 - 3 } & Zagreb arm & \\
\hline Vitamins and minerals & 508 & 56.9 \\
Diazepam & 303 & 33.9 \\
Iron and folic acid & 297 & 33.3 \\
Oxytetracyclin + nystatin & 227 & 25.4 \\
Tocolytics & Novi Sad arm & \\
Iron & 536 & 26.6 \\
Vitamins and minerals & 297 & 21.3 \\
Antimicrobials & 227 & 20.3 \\
\hline
\end{tabular}

Epidemiological methods were employed in the study because clinical therapeutic trials in pregnant women are highly restricted by current ethical principles. The trial was designed as a cross-sectional study to determine exposure of pregnant women to a particular drug, their disease status, and their newborns' conditions. Using this method, the prevalence of malformations and pathologic states was determined in the neonates born to mothers at a particular drug exposure versus neonates born to mothers free from such a drug exposure.

All drugs including vitamins, minerals and iron supplements taken by study women during pregnancy were classified according to safety level into five FDA categories.

Our study has the approvals of all relevant ethics committees from all maternity hospitals. All women have given written informed consent.

Statistical analysis. Student's $t$-test and Chi-square test with a significance level of $p \leq 0.05$ were used when appropriate for the evaluation of the results. All analysis were performed with SigmaStat 3.0 for Win dows (SPSS Science software products, Chicago, IL, U. S.).

Results and Discussion. The prevalence of congenital malformations in the general population was $2.91 \%(n=26)$ in Zagreb and $5.35 \%(n=326)$ in Novi 
Table 2

Maternal use of vitamins, minerals, iron supplements and folic acid, and congenital malformations - Zagreb arm

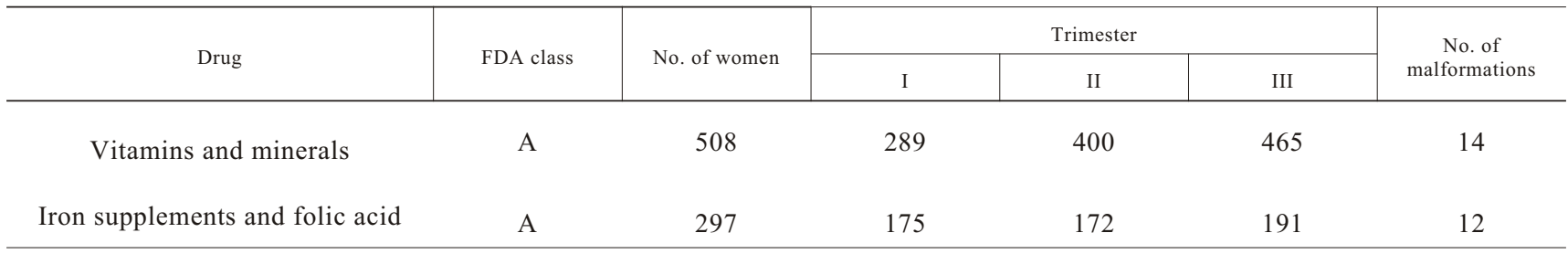

FDA $=$ Food and Drug Administration

Table 3

Congenital malformations according to organ systems involved

\begin{tabular}{c|c|c|c|c|c|c|c|c|c|}
\hline \multirow{2}{*}{ Drug } & \multicolumn{7}{c}{ Organ system involved } & \multicolumn{2}{c}{ Total } \\
\cline { 2 - 9 } & $\mathrm{CV}$ & $\mathrm{GU}$ & $\mathrm{HN}$ & $\mathrm{MS}$ & Resp & Abd & Skin & Unknown & 1 \\
\hline Vitamins and minerals & 5 & 3 & - & 2 & - & 1 & 2 \\
Iron supplements and folic acid & 2 & 4 & 1 & 2 & 2 & - & - & 1 \\
\hline
\end{tabular}

$\mathrm{CV}=$ cardiovascular; $\mathrm{GU}=$ genitourinary $; \mathrm{HN}=$ head and neck; $\mathrm{MS}=$ musculoskeletal; Resp = respiratory; Abd = abdominal.

Sad. The four leading drugs in Zagreb and Novi Sad are shown in Table 1. The prevalence of congenital malformations in fetuses and neonates at in utero drug exposure was $3.03 \%(n=26)$ in Zagreb and $5.61 \%$ $(n=113)$ in Novi Sad.

The vitamins, minerals, iron supplements and folic acid used during pregnancy and malformations detected in these fetuses or newborns in Zagreb are presented in Tables 2 and 3. The number of women taking these supplements increased with gestational age. The prevalence of congenital malformations in fetuses and neonates at prenatal exposure to the action of vitamins and minerals was $2.76 \%(n=14)$ and was quite comparable to the rate found in the general population $(n=26 ; 2.91 \%)$. In fetuses and neonates at prenatal exposure to iron supplements and folic acid, the prevalence of congenital malformations was $4.04 \%(n=12)$, exceeding the rate found in the general population; however, the difference did not reach statistical significance.

The use of calcium during pregnancy increased from $3.4 \%(n=30)$ in first trimester through $5.3 \%$ $(n=47)$ in second trimester to $5.7 \%(n=51)$ in third trimester. It should be noted that study women reported negligible or no use of calcium before pregnancy. Malformations were found in four fetuses and neonates with prenatal exposure to calcium.
The vitamins, minerals and iron supplements used in pregnancy and malformations detected in these fetuses or newborns in Novi Sad are presented in Table 4.

The prevalence of congenital malformations in fetuses and neonates at in utero exposure to vitamins and minerals was $4.17 \%(n=17)$, which was below the rate found in the general population ( $n=326 ; 5.35 \%)$, however, the difference was not statistically significant. In fetuses and neonates at prenatal exposure to iron supplements, the prevalence of congenital malformations was $3.03 \%(n=13)$, which was also below the rate found in the general population and the difference was statistically significant $\left(\chi^{2}=4.36, p<0.05\right)$. In fetuses and neonates at prenatal exposure to folic acid, the prevalence of congenital malformations was $15.39 \%$ $(n=2)$, considerably exceeding the rate found in the general population; however, the difference was not statistically significant.

In the Novi Sad arm, positive correlation was recorded between gestational age and the rate of vitamin, mineral and iron supplementation. Besides the use of vitamins and minerals in pregnancy, exposure to other adverse factors was recorded in 25 pregnant women in Novi Sad (Table 5).

There was no statistically significant difference in the rate of congenital malformations according to the use of study substances between Zagreb and Novi Sad. 
Table 4

Maternal use of vitamins, minerals, iron supplements and folic acid, and congenital malformations - Novi Sad arm

\begin{tabular}{c|c|c|c|c|c|c|c}
\hline \multirow{2}{*}{ Drug } & \multirow{2}{*}{ FDA class } & \multirow{2}{*}{$\begin{array}{c}\text { No. of } \\
\text { women }\end{array}$} & \multicolumn{2}{|c|}{ Trimester } & $\begin{array}{c}\text { No. of } \\
\text { malformations }\end{array}$ & Malformations \\
$\begin{array}{c}\text { Vitamins and } \\
\text { minerals }\end{array}$ & A & 408 & 47 & 267 & 398 & 17 & $\begin{array}{l}\text { Right ear otopostasis, right kidney hydronephrosis, } \\
\text { pes valgus }(n=3), \text { frenulum linguae breve }(n=10), \\
\text { hydrocephalus, diastasis m. recti abdominis }\end{array}$ \\
$\begin{array}{c}\text { Ferrosulfate } \\
\text { Folic acid }\end{array}$ & A & 429 & 11 & 142 & 418 & 13 & $\begin{array}{l}\text { Cleft palate, atrial septal defect, pes valgus }(n=4), \\
\text { frenulum linguae breve }(n=6), \text { micrognathia }\end{array}$ \\
\hline
\end{tabular}

FDA $=$ Food and Drug Administration

Table 5

Novi Sad arm women exposed to additional noxae

\begin{tabular}{c|c|c|c}
\hline Drug & Trimester & Additional noxae & Fetal findings \\
\hline Vitamins and minerals & II and III & $<10$ cigarettes daily in 12 women & $\begin{array}{c}\text { Right kidney hydronephrosis and frenulum } \\
\text { linguae breve in one case each }\end{array}$ \\
& III & Dental X-ray in first trimester & Normal finding \\
& III & Pelvis X-ray in first trimester & Normal finding \\
& II and III & Maternal age $>35$ in 12 women & $\begin{array}{c}\text { Hydrocephalus and frenulum linguae breve } \\
\text { in one case each }\end{array}$ \\
\hline
\end{tabular}

The effect of the potential teratogens on the course and outcome of pregnancy does not only depend on the gestational age at exposure but also on the amount and dosage of teratogen exposure. This can best be exemplified by vitamin A, as both vitamin A deficiency and hypervitaminosis have a teratogenic potential. The present study suffered from some methodological limitations, i. e. use of a questionnaire answered by the study women, where the possible errors in recollection as well as the impact of educational level and personality on the answers could not be ruled out. Therefore, data were in part collected from hospital records. Considering the length of the study, seasonal effects on the study results could not be ruled out either. In large international studies, data have been increasingly derived from network databases on prescription drugs, thus minimizing the possible errors $[8,9]$. In the present study, the Zagreb arm showed the vitaminmineral supplements to be most frequently prescribed to pregnant women, whereas in Novi Sad these supplements ranked third. According to this parameter, the two study populations did not differ from other settings included in similar studies, where vitamins and minerals also predominated in drug utilization during pregnancy $[10,11]$. According to a cross-sectional study from Addis Ababa, Ethiopia, iron and vitamins accounted for the majority of drugs prescribed in Africa [12].

On the other side of the world, in western Nepal, the most commonly prescribed drugs were dietary supplements like iron, folate, calcium, and vitamins (72.8\%) [13].

Teratogenicity of vitamin A hyper- and hypovitaminosis has been reported from previous studies. High doses of vitamin A lead to the occurrence of cleft palate, spina bifida, anencephaly, lung agenesis or hypoplasia, and malformations of genitourinary and gastrointestinal system, whereas vitamin A deficiency results in congenital xerophthalmia, anophthalmia, retinal detachment, microcephaly, and cleft lip [14]. High dietary intake of preformed vitamin A appears to be teratogenic. Rothman et al. estimated that one of 57 
infants born to women having used more than 10,000 IU of preformed vitamin A per day in the form of supplements had a malformation attributable to the supplement [15].

Vitamin $B_{12}$ deficiency leads to fetal development of megaloblastic anemia, while there are no data on the adverse effects of vitamin $\mathrm{B}_{12}$ high doses. Vitamin $\mathrm{C}$ deficiency results in impaired neural tube development, while hypervitaminosis $\mathrm{C}$ has been associated with isolated cases of anencephaly. Maternal vitamin D insufficiency is common during pregnancy and is associated with reduced bone-mineral accrual in the offspring during childhood. Excessive doses of vitamin D may lead to mental retardation, retarded physical development, strabismus, craniosynostosis, supravalvular aortic stenosis, inguinal hernia, cryptorchidism in male fetuses, and premature development of secondary sexual characteristics in female fetuses [16]. Low maternal vitamin $\mathrm{E}$ intake during pregnancy is associated with asthma in 5-year-old children [17].

When administered in low daily doses, vitamins are classified as fetal risk category A. However, if taken in high doses, vitamins can exert adverse effects on fetal development and lead to congenital malformations. In this context, vitamin A is classified as fetal risk category $\mathrm{X}$, vitamin $\mathrm{D}$ as category $\mathrm{D}$, and other vitamins as category C [18].

There are no literature data on the possible teratogenic effect of minerals. Important problem during pregnancy is the deficit of micronutrient and therefore supplementation can alleviate deficiencies, but supplements must be taken for an adequate period of time [19].

Analysis of our study results and the high utilization of vitamins in pregnancy showed that there was no statistically significant difference between the prevalence of congenital malformations in fetuses and neonates at prenatal exposure to vitamins or vitaminmineral supplements and the prevalence of congenital malformations in the general population. Accordingly, maternal use of these substances was not associated with the occurrence of congenital malformations.

Considering the structure of malformations, prenatal exposure to vitamins or complex vitamin supplements was mainly associated with minor congenital malformations, whereas major malformations were on- ly recorded in two cases (hydrocephalus and hydronephrosis). However, fetal exposure to other harmful noxae was involved in both cases and these adverse effects were more likely the cause of malformation and functional impairment than the maternal intake of vitamins or vitamin complexes.

Analysis of calcium intake by mothers to children with congenital malformations yielded a statistically significant difference at the level of $\mathrm{p}<0.05$ in the rate of congenital malformations between the infants at prenatal calcium exposure and those free from it, suggesting an association of maternal calcium intake and congenital malformations. However, there was no statistically significant difference at the level of $\mathrm{p}<0.01$. The search through relevant literature failed to yield similar results, suggesting suspicion towards uncontrolled use of various vitamin-mineral supplements in pregnancy.

Analysis of maternal use of iron supplements (in Zagreb arm) produced a statistically significant difference in the rate of congenital malformations between the neonates at in utero iron exposure and those free from this exposure, pointing to an association between maternal iron intake and congenital malformations. This finding differed from previous studies that found no association between congenital malformations and use of iron supplements in pregnancy [20].

However, our results support the authors that disapprove uncritical iron prescribing [21], since some $10 \%$ of non-pregnant women of reproductive age suffer from anemia. In the Novi Sad arm, there was no statistically significant difference between the infants at prenatal iron exposure and those without it.

In the present study, the possible effect of particular vitamins on fetal health could not be determined because the great majority of study women used combined multivitamin-mineral supplements. Therefore, the possible effect of a particular vitamin on fetal malformations could not be identified.

Conclusions. Additional studies are needed to investigate the maternal and fetal effects of mineral supplementation. The use and promotion of vitaminmineral supplementation should be discouraged and abandoned, at least in pregnancy. Instead, the use of monocomponent supplementation of any vitamin or 
mineral with demonstrated deficiency should be supported. For this purpose, it is advised to analyze the effect of each individual vitamin and mineral, in our setting iron and calcium.

In spite of the limitations mentioned above, our study pointed to the possible too much utilization of vitamins and minerals during pregnancy in Zagreb women and offered an opportunity to improve the quality of therapy in this vulnerable period of life. The study highlighted the issue of reasonable utilization and the need of developing guidelines for the use of vitamins, minerals, iron and folic acid supplementation, considering that these substances are available as over-the-counter drugs. And the last but not the least, the first trimester deserves due attention and management as the most vulnerable period of fetal development.

Acknowledgements. We would thank all monitors participating to collect data for this study, and all physicians collaborating of hospital structures involved into the study: University Departments of Gynecology and Obstetrics in four Zagreb hospitals: Zagreb University Hospital Center, Sestre milosrdnice University Hospital, Merkur University Hospital and Sveti Duh General Hospital and in these institutions in Novi Sad: Genetic Counseling Unit, Institute for Children and Adolescents, University Department of Gynecology and Obstetrics, and Department of Pathology and Histology, Clinical Center in Novi Sad.

\section{М. Ліпе, Дж.Куліг, М. Ерік, Дж. Боскович, Н. Колак}

Вітамини, мінерали і добавки заліза при вагітності: перехресне вивчення

Резюме

Мета. Оиінити вживання вітаминів, а також харчових добавок, які містять мінерали $i$ залізо, протягом вагітності жінок із Загреба та Нові-Сада. Методи. Дослідження проводили із використанням стандартного структурованого опитування, яке складається з двох частин: даних, одержаних під час інтерв'ю, та лікарняних записів. Воно побудовано як кроссекиійне дослідження у двох крайнах (Хорватії $i$ Сербії). Досліджували 893 вагітні жінки із Загреба та 6099 вагітних жінок з Нові-Сада. Результати. У вагітних жінок із Загреба відмічено найвище вживання вітамінно-мінеральних добавок ( $n=508 ; 56.9 \%)$, у той час як у Нові-Саді воно виявилося в три рази нижчим ( $=408 ; 20.3 \%)$, включаючи токолітики - препарати, які попереджують передчасні пологи, і добавки заліза. Не виявлено статистичено достовірних розбіжностей у частоті появи вроджених дефектів розвитку у новонароджених, які в пренатальному періоді отримували або не отримували добавки, які містять вітаміни, мінерали $і$ залізо, в обох регіонах, за винятком добавок із залізом та кальиієм у загребській вибориі. Выводы. Незважаючи на певні обмеження у дослідженні, результати свідчать про необгрунтоване та потениійно шкідливе застосування таких добавок серед вагітних жінок у Загребі.

Ключові слова: вітаміни, мінерали, вагітність, Загреб, Нові-Сад.

М. Липе, Дж.Кулиг, М. Эрик, Дж. Боскович, Н. Колак

Витамины, минералы и добавки железа при беременности: перекрестное изучение

Резюме

Цель. Оиенить применение витаминов, а также пищевых добавок, содержащих минераль и железо, во время беременности у женщин, проживающих в Загребе и Нови-Саде. Методы. Исследование проводили с использованием стандартного структурированного опроса, состоящего из двух частей: данных, полученных в ходе интервью, и записей в больницах. Оно построено как кросс-секционное исследование в двух странах (Хорватии и Сербии). Исследовано 893 беременные женщины из Загреба и 6099 - из Нови-Сада. Результаты. У беременных женщин из Загреба отмечено наиболее высокое употребление витаминно-минеральных добавок ( $n=508 ; 56.9 \%)$, в то время как в Нови-Саде оно оказалось в три раза ниже ( $n=408$; $20.3 \%$ ), включая токолить - препарать, предотвращающие преждевременные роды, и добавки железа. Не выявлено статистически достоверных различий в частоте появления врожденных дефектов развития у новорожденных, которые в пренатальном периоде получали или не получали добавок, содержаших витамины, минералы и железо, в обоих регионах, за исключением добавок с железом и кальиием в загребской выборке. Выводы. Несмотря на определенные ограничения в исследовании, результаты свидетельствуют о необоснованном и потенциально вредном применении этих добавок среди беременных женщин в Загребе.

Ключевые слова: витамины, минераль, беременность, Загреб, Нови-Сад.

\section{REFERENCES}

1. Jackson A. A., Robinson S. M. Dietary guidelines for pregnancy: a review of current evidence // Publ. Health Nutr.-2001.4, N 2B.-P. 625-630.

2. Kind K. L., Moore V. M., Davies M. J. Diet around conception and during pregnancy - effects on fetal and neonatal outcomes // Repr. Biomed. Online.-2006.-12, N 5.-P. 532-541.

3. Glenville $M$. Nutritional supplements in pregnancy: commercial push or evidence based? // Curr. Opin. Obstet. Gynecol.2006.-18, N 6.-P. 642-647.

4. Collaborative Group on Drug Use in Pregnancy (CGDUP). Medication during pregnancy: an intercontinental cooperative study // Int. J. Gynecol. Obstet.-1992.-39, N 3.-P. 185196.

5. Bonati M., Bortolus R., Marchetti F., Romero M., Tognoni G. Drug use in pregnancy: an overview of epidemiological (drug utilization) studies // Eur. J. Clin. Pharmacol.-1990.38, N 4.-P. 325-328. 
6. Lacroix I., Damase-Michel C., Lapeyre-Mestre M., Montastruc J. L. Prescription of drugs during pregnancy in France // Lancet.-2000.-356, N 9243.-P. 1735-1736.

7. Beyens M. N., Guy C., Ratrema M., Ollagnier M. Prescription of drugs to pregnant women in France: the HIMAGE study // Therapie.-2003.-58, N 6.-P. 505-511.

8. Shah M. D., Shah S. R. Nutrient deficiencies in the premature infant // Pediatr. Clin. North Am.-2009.-56, N 5.-P. 10691083.

9. Leppee M. Drugs in pregnancy. PhD thesis. School of Medicine, Josip Juraj Strossmayer University.-Osijek, 2008.

10. Egen-Lappe V., Hasford J. Drug prescription in pregnancy: analysis of a large statutory sickness fund population // Eur. J. Clin. Pharmacol.-2004.-60, N 9.-P. 659-666.

11. Piper J. M., Baum C., Kennedy D. L. Prescription drug use before and during pregnancy in a Medicaid population // Am. J. Obstet. Gynecol.-1987.-157, N 1.-P. 148-156.

12. Kebede B., Gedif T., Getachew A. Assessment of drug use among pregnant women in Addis Ababa, Ethiopia // Pharmacoepidemiol. Drug Saf.-2009.-18, N 6.-P. 462-468.

13. Das B., Sarkar C., Datta A., Bohra S. A study of drug use during pregnancy in a teaching hospital in western Nepal // Pharmacoepidemiol. Drug Saf.-2003.-12, N 3.-P. 221-225.

14. Mills J. L., Simpson J. L., Cunningham G. C., Conley M. R., Rhoads G. G. Vitamin A and birth defects // Am. J. Obstet. Gynecol.-1997.-177, N 1.-P. 31-36.

15. Rothman K. J., Moore L. L., Singer M. R., Nguyen U. S., Mannino S., Milunsky A. Teratogenicity of high vitamin A intake // N. Engl. J. Med.-1995.-333, N 21.-P. 1369-1373.
16. Javaid M. K., Crozier S. R., Harvey N. C., Gale C. R., Dennison E. M., Boucher B. J., Arden N. K., Godfrey K. M., Cooper $C$. Maternal vitamin D status during pregnancy and childhood bone mass at age 9 years: a longitudinal study // Lancet.2006.-367, N 9504.-P. 36-43.

17. Devereux G., Turner S. W., Craig L. C., McNeill G., Martindale S., Harbour P. J., Helms P. J., Seaton A. Low maternal vitamin $\mathrm{E}$ intake during pregnancy is associated with asthma in 5-year-old children // Am. J. Respir. Crit. Care Med.2006.-174, N 5.-P. 499-507.

18. Briggs G. G., Freeman R. K., Yaffe S. J. Drugs in pregnancy and lactation: $5^{\text {th }}$ ed.-Baltimore: Williams and Wilkins, 1998.-1219 p.

19. Huskisson E., Maggini S., RufM. The role of vitamins and minerals in energy metabolism and well-being // J. Int. Med. Res.-2007.-35, N 3.-P. 277-289.

20. Seligman P. A. Measurment of iron absorption from prenatal multivitamin-mineral supplements // Obstet. Gynecol.1983.-61, N 3.-P. 356.

21. De Jong-van den Berg L. T., Van den Berg P. B., HaaijerRuskamp F. M., Dukes M. N., Wesseling H. Investigating drug use in pregnancy. Methodological problems and perspectives // Pharm. Weekbl. (Sci.).-1991.-13, N 1.-P. 32-38.

UDC 618.2-083:612.015.6

Received 12.01 .10 